\title{
Psychosocial Factors That May Help Make Exercise Programs For Prostate Cancer Patients Self- Sustaining: Two Case Studies
}

Isaac Nikolai Fox

Independent Scholar

Richard J. Wassersug ( $\nabla$ richard.wassersug@ubc.ca )

University of British Columbia https://orcid.org/0000-0001-7028-7615

\section{Research Article}

Keywords: social support, physical exercise, androgen deprivation, exercise therapy

Posted Date: July 6th, 2021

DOI: https://doi.org/10.21203/rs.3.rs-600113/v1

License: (c) (i) This work is licensed under a Creative Commons Attribution 4.0 International License.

Read Full License 


\section{Abstract}

\section{Purpose}

Prostate cancer ( $\mathrm{PCa}$ ) patients benefit from regular exercise, but it is difficult for patients to maintain an exercise regime. We examined two exercise programs that have proven to be self-sustaining with the goal of identifying features they share that may contribute to their success.

\section{Methods}

We compared the FC Prostata football (soccer) league in Denmark and the "Butts in a Boat" (BIAB) dragon-boating team in Canada. The FC Prostata project coordinator and the BIAB leaders provided information on the programs' histories and structures.

\section{Results}

Both programs are team-based with regular, intense exercise at their core. In both cases, social activities spontaneously evolved, starting with the men going out for food and/or drinks after practices.

The sustainability of these programs appears to be driven by the regular socialization that is linked to the fitness activities.

\section{Conclusions}

Our two case studies suggest that exercise programs for prostate cancer patients may have a good chance of being self-sustaining, if they are: 1) centered around intense exercise, 2) of a team nature, 3) structured to promote egalitarianism and avoid one-on-one competition within teams, yet 4) have some competitions between teams.

Informal socialization organized by patients after team practice appears particularly important for building fellowship and strengthening patients' commitment to exercise for themselves and social support for others.

\section{Introduction}

Physical exercise (PE) is considered one of the best ways to combat many of the adverse effects of PCa treatments $[1,3,7]$ and may help delay disease progression and improve survival $[24,27,29]$. Exercise therapy is considered "safe, feasible, and effective" even for PCa patients with limited metastatic disease [24]. It can relieve cancer-related fatigue, sarcopenia and improve the quality of life (QoL) for men on androgen deprivation therapy (ADT) $[24,32,38]$. Preclinical research also indicates that exercise may slow tumor growth and enhance the efficacy of chemotherapy treatment [24]. Benefits of PE have been documented for both resistance and aerobic exercise for men with both early and advanced disease [14$15,20-22,26,31]$. 
Social connections are also critically important for PCa patients. Low perceived social support is linked to increased symptom severity for PCa patients $[13,19]$. Social isolation for cancer patients in general has been linked to higher levels of depression, stress, and lower QoL [2,3,25]. Although a multitude of inperson and online PCa support groups now exist, many focus on providing information about treatment decisions and managing treatment side effects. Although valuable, that is not the same as providing social support at a level that may improve health-related QoL.

Researchers are still exploring the most effective PE protocol for PCa patients. The literature suggests that supervised group PE has the greatest positive impacts on ADT-related symptoms and patient QoL [15]. A recent review though noted that none of the research on exercise interventions for PCa patients assessed reversibility; i.e. none assessed how long the men sustained their exercise programs after the research trials ended [28]. It is not known what factors motivate PCa patients to stick with PE in the longterm.

Here, we detail two case studies on PE programs for PCa patients, both of which have proven sustainable for more than a half decade outside of clinical care or any research programs. Both programs involve team sports and stand out for having maintained activity and team cohesion, even when the COVID-19 pandemic prohibited in-person practices and competition. Both of the programs have PE and social activities linked to fitness. Furthermore, both have been documented in the academic literature. The first is the Danish FC Prostata league [4-5, 33-35]. The other is the Butts in a Boat (BIAB) dragon-boating team in Vancouver, Canada [12].

FC Prostata is a football league that is managed nationally by the Danish Football Association (Dansk Boldspil-Union, hence DBU; https://www.dbu.dk/). Two DBU staff members provide organizational support to FC Prostata. The BIAB team is officially sponsored by the Prostate Cancer Foundation of British Columbia (PCFBC, https://www.prostatecancerbc.ca/home/), but BIAB activities are organized by the members themselves.

Here, we compare and contrast these programs in order to identify common features of their success as self-sustaining PE programs for PCa patients. We also identify shared challenges that the programs face in assuring their continuity.

\section{Method}

In addition to the published literature, information on FC Prostata was obtained from the FC Prostata project coordinator. Demographic and observational information about the BIAB team was obtained via a convenience sample, facilitated by the captain and one of the cofounders of the dragon-boating team. They provided details on the ages of the active members as well as their first-hand knowledge of the team's history and the health status of the members.

Some observations on a third program, Herlev Hospital's Feel+, whose membership is restricted to advanced PCa patients on ADT, are also included. Feel + patients have group PE in one-off cohorts of 
three months. We did not include this program as one of our primary case studies because it is not a team sport-based program. However, it shares many features with the FC Prostata and BIAB program that have helped recruit new patients and build their long-term commitments to PE. Information on the program was provided by a physiotherapist who helps lead that program.

Basic information on and images of the BIAB team from various years are available at: http://buttsinaboat.ca/. Similar information on FC Prostata teams is available at: https://www.dbu.dk/samfundsansvar/projekter-og-indsatser/fc-prostata/.

\section{Results}

Features of the FC Prostata and BIAB programs are presented in Table 1 followed by text summarizing major similarities and differences between the two programs. 
Table 1

Features of the BIAB and FC Prostata programs

\begin{tabular}{|c|c|c|c|c|c|}
\hline $\begin{array}{l}\text { Variable } \\
\text { Type }\end{array}$ & Variable & $\begin{array}{l}\text { Butts } \\
\text { in a } \\
\text { Boat }\end{array}$ & Details & $\begin{array}{l}\text { FC } \\
\text { Prostata }\end{array}$ & Details \\
\hline \multirow[t]{7}{*}{$\begin{array}{l}\text { Quantitative } \\
\text { Data }\end{array}$} & Year founded & 2016 & $\begin{array}{l}\text { Founded for one-off } \\
\text { competition against } \\
\text { breast cancer group. }\end{array}$ & 2014 & $\begin{array}{l}\text { Founded for } \\
\text { study on } \\
\text { exercise therapy } \\
\text { for ADT } \\
\text { patients. }\end{array}$ \\
\hline & \# of participants & 25 & - & 214 & - \\
\hline & $\begin{array}{l}\text { Mean age } \\
\text { (years) }\end{array}$ & $\begin{array}{l}72.3 \\
\pm 5.3\end{array}$ & - & $\begin{array}{l}68.2 \pm \\
6.2\end{array}$ & - \\
\hline & $\begin{array}{l}\text { Oldest } \\
\text { participant }\end{array}$ & 81 & - & - & $\begin{array}{l}\text { No available } \\
\text { data. }\end{array}$ \\
\hline & $\begin{array}{l}\text { Youngest } \\
\text { participant }\end{array}$ & 64 & - & - & $\begin{array}{l}\text { No available } \\
\text { data. }\end{array}$ \\
\hline & $\begin{array}{l}\text { Participants per } \\
\text { team }\end{array}$ & $\begin{array}{l}22- \\
28\end{array}$ & $\begin{array}{l}25 \text { at present, team size } \\
\text { has varied }\end{array}$ & $12-15$ & $\begin{array}{l}\text { Smallest team } \\
\text { has } 4-6 \text { players, } \\
\text { largest has } 20- \\
25\end{array}$ \\
\hline & $\begin{array}{l}\text { Number of } \\
\text { teams }\end{array}$ & 1 & - & 20 & - \\
\hline \multirow[t]{7}{*}{$\begin{array}{l}\text { Categorical } \\
\text { features }\end{array}$} & $\begin{array}{l}\text { Year-Round } \\
\text { Training }\end{array}$ & YES & $\begin{array}{l}\text { Group fitness instead of } \\
\text { dragon-boating during } \\
\text { the off-season. }\end{array}$ & YES & - \\
\hline & Co-Ed team & NO & - & NO & - \\
\hline & $\begin{array}{l}\text { Does } \\
\text { participation } \\
\text { cost money? }\end{array}$ & YES & $\begin{array}{l}\$ 10 \mathrm{CAD} / \text { class, plus } \\
\text { regatta registration fees. }\end{array}$ & YES & $\begin{array}{l}\$ 40-75 \text { USD per } \\
\text { six-month } \\
\text { season. }\end{array}$ \\
\hline & $\begin{array}{l}\text { Rural, urban or } \\
\text { both? }\end{array}$ & Urban & - & Both & $\begin{array}{l}\text { Primarily urban, } \\
\text { a few teams in } \\
\text { smaller cities. }\end{array}$ \\
\hline & $\begin{array}{l}\text { Socialization } \\
\text { linked to } \\
\text { training } \\
\text { sessions? }\end{array}$ & YES & $\begin{array}{l}\text { Drinks at a nearby pub } \\
\text { or restaurant. }\end{array}$ & YES & $\begin{array}{l}\text { Breakfasts and } \\
\text { lunches after } \\
\text { training; outings } \\
\text { to pubs. }\end{array}$ \\
\hline & $\begin{array}{l}\text { Socialization } \\
\text { not linked to } \\
\text { fitness training? }\end{array}$ & YES & $\begin{array}{l}\text { Monthly billiards nights, } \\
\text { subgroups also } \\
\text { golf/cycle. }\end{array}$ & YES & - \\
\hline & $\begin{array}{l}\text { Is socialization } \\
\text { organized by } \\
\text { players? }\end{array}$ & YES & $\begin{array}{l}\text { Spouses helped } \\
\text { organize socialization } \\
\text { early-on. }\end{array}$ & YES & $\begin{array}{l}\text { Coaches } \\
\text { facilitated } \\
\text { socialization in } \\
\text { the beginning. }\end{array}$ \\
\hline
\end{tabular}




\begin{tabular}{|c|c|c|c|c|c|}
\hline $\begin{array}{l}\text { Variable } \\
\text { Type }\end{array}$ & Variable & $\begin{array}{l}\text { Butts } \\
\text { in a } \\
\text { Boat }\end{array}$ & Details & $\begin{array}{l}\text { FC } \\
\text { Prostata }\end{array}$ & Details \\
\hline & $\begin{array}{l}\text { Exercise during } \\
\text { COVID-19? }\end{array}$ & YES & $\begin{array}{l}\text { Replaced with group } \\
\text { fitness in a park and } \\
\text { weekly Zoom calls. }\end{array}$ & NO & - \\
\hline & $\begin{array}{l}\text { Do spouses } \\
\text { attend } \\
\text { practices? }\end{array}$ & NO & $\begin{array}{l}\text { On occasion, yes, but } \\
\text { generally no. }\end{array}$ & NO & - \\
\hline & $\begin{array}{l}\text { Hospital-driven } \\
\text { recruitment? }\end{array}$ & NO & - & YES & $\begin{array}{l}\text { Ongoing } \\
\text { hospital } \\
\text { recruitment. }\end{array}$ \\
\hline & $\begin{array}{l}\text { Word-of-mouth } \\
\text { recruitment? }\end{array}$ & YES & - & YES & - \\
\hline & $\begin{array}{l}\text { Is training } \\
\text { coached? }\end{array}$ & YES & - & YES & - \\
\hline & $\begin{array}{l}\text { Are coaches PC } \\
\text { survivors? }\end{array}$ & YES & $\begin{array}{l}\text { Group fitness instructor } \\
\text { is not a PCa survivor. }\end{array}$ & YES & $\begin{array}{l}>75 \% \text { of } \\
\text { coaches are } \\
\text { PCa patients. }\end{array}$ \\
\hline & $\begin{array}{l}\text { Do coaches } \\
\text { receive training? }\end{array}$ & YES & - & YES & - \\
\hline & $\begin{array}{l}\text { Standardized } \\
\text { practice } \\
\text { structure? }\end{array}$ & YES & - & YES & - \\
\hline
\end{tabular}

\section{Team origins}

FC Prostata arose as part of a multicenter clinical investigation by urologists into the impact of football on ADT side effect severity and patients' QoL [5]. Participants elected to continue with the program after the trial ended and have now expanded to twenty teams.

BIAB was started by two PCa patients who were inspired by "Abreast in a Boat" (https://abreastinaboat.com/), a dragon-boating team for breast cancer survivors that was initially a research project, but continued on its own after the research ended and proliferated globally into teams across 29 countries $[11,23]$. The co-founders of BIAB recruited a team for a one-off competition against the current-day original "Abreast in a Boat" team. BIAB participants were recruited through word-of-mouth, and promoted by the Prostate Cancer Foundation of British Columbia (PCFBC, https://www.prostatecancerbc.ca/) and the Vancouver Prostate Center (VPC, https://www.prostatecenter.com/). The dragon-boating season in Vancouver lasts from May through October, so the team organized regular fitness classes at a local recreation center to maintain fitness and continuity in the off-season. 


\section{Participant demographics}

There were 214 FC Prostata players in the original research study with an average age of $68.2 \pm 6.2$ years old [5]. As of November 2020, the 25 active BIAB paddlers had an average age of $72.3 \pm 5.3$ years old (range 64-81). These members had been on the team for one to five years, with the majority having been participating for more than 3 years. A two-tailed t-test found no statistical difference $(p=0.938)$ between the mean ages of the men at the time each team was founded ( $68.3 \pm 5.3$ for BIAB), indicating that the programs serve men of comparable age.

Exact demographic data was not available for FC Prostata, although the league's project manager specified that the men were predominantly white and of higher income status. The demographic profile of the BIAB team is narrow, and currently has only white men of a relatively high socioeconomic status. Although not all participants have a post-secondary education, the group includes at least one PhD and two physicians. None of the individuals on the team are conspicuously obese nor are any tobacco users.

\section{Disease status}

The men in both groups range from those on active surveillance to some with metastatic disease. Most FC Prostata and BIAB participants have received primary PCa treatments including prostatectomies and radiotherapy treatments, with or without adjuvant ADT. Some participants in both groups are on sustained ADT for advanced disease.

FC Prostata does not collect data on the disease statuses of members, but the league's Project Coordinator estimated that more than $90 \%$ of the players had been or were currently on ADT. Current BIAB members range from two on active surveillance to at least five experiencing biochemical progression after primary treatment.

\section{Team structure}

FC Prostata teams typically have 12-15 (range 4-25) members. The teams train by themselves during regular practices, but also take part in annual league wide tournaments. BIAB is a solitary team and not part of a league. BIAB trains in Vancouver waterfront. The team has remained stable with $~ 25$ members throughout its history.

\section{Training season}

FC Prostata and BIAB both train year-round, although for BIAB, the PE shifts from dragon-boating in the summer to group fitness classes during the off-season.

\section{Recruitment}

Recruitment for FC Prostata teams is primarily done through Danish hospitals. All seven Danish oncology departments and a number of urology departments refer patients to the league. Once FC Prostata teams have become established locally, recruitment for participants shifts to being primarily through word-ofmouth. 
Recruitment for BIAB is also done primarily through word-of-mouth. PCa patients may also learn about the group's exercise programming from their oncologists, the PCFBC or the VPC. The involvement of these health institutions is informal. Several current BIAB members began dragon-boating after having first started in the off-season exercise group.

\section{Practice structure}

FC Prostata practices have three 20-minute blocks. The first is warm-up, involving stretching and resistance exercise. This is followed by 20 minutes of technical football drills, before ending with an open (20 min) scrimmage. For the scrimmage, the club divides into two teams, consciously equalizing the skill level of the team players.

BIAB also has standardized practices, which vary depending on the season. During the dragon-boating season, practices begin with warm-up exercises on land. This is followed by warm-up paddling on the water followed by endurance drills, all led by the team captain. The training sessions end with brief cooldown paddling. During the off-season, the format of training shifts to indoor fitness sessions at a local recreation center. These sessions take place twice per week and are led by a trained fitness instructor.

\section{Coaching}

Coaches for FC Prostata are recruited by the DBU. The DBU provides a full training manual for coaches. The manual is detailed enough that one does not need previous football coaching experience. The manual Emphasizes an egalitarian philosophy that encourages cooperation rather than competition among the men such that players of all skill and fitness levels can train together without frustration or humiliation.

Coaching for BIAB was initially informal and led by a co-founding patient who was an experienced dragon-boater. In recent years, the team has hired professional dragon boat coaches for their on-the-water practices. An untrained participant, who is a regular member of the team, has been leading group fitness via online videoconferencing during the COVID-19 pandemic while in-person exercise has been suspended.

\section{Socialization linked to exercise}

Exercise-linked socialization appears to be a major contributor to FC Prostata's sustainability. Generally, socializing is player-organized and involves gathering at local restaurants and pubs after practices.

Coaches may play a minor role in encouraging players to socialize after practices early-on, but once the team bonds are solidified, the players organize outings themselves. The DBU does not facilitate social events for the players but did report informal data suggesting that this was key to the players' commitment to attending regular practices.

BIAB's exercise-linked social activities evolved spontaneously, starting with the paddlers going to a local bar after dragon-boating and fitness sessions. The spouse of one team member encouraged the team to reconvene at a nearby pub after exercising, which the players have since taken as their custom. 


\section{Socialization not linked to exercise}

There is no formal data regarding socialization for FC Prostata team members outside of normal practices. The teams do hold what they euphemistically call 'training camps', which are social walks involving food and drinks, accompanied by players' spouses.

Socialization not linked to PE has proven to be an important part of BIAB. In 2017 through early 2020 (i.e., pre-COVID-19), this included monthly billiards evenings. Additional social groups have formed whose group activities include bicycling and golf. BIAB members and their spouses now commonly also have dinners or picnics together apart from exercise sessions.

\section{Spousal involvement}

Spouses do not participate in FC Prostata team practices, although they are invited to attend the previously mentioned 'training camps.' BIAB is open to spousal participation in the off-season exercise classes, although it is not the norm. Spouses will occasionally attend fitness classes and after-exercise social events. One spouse helps manage the regatta competitions. Spousal involvement in BIAB has deepened throughout the COVID-19 pandemic. Recent online exercise sessions have included up to three spouses along with $23 \mathrm{PCa}$ participants.

\section{COVID-19}

Public health measures instituted to reduce the spread of COVID-19 curtailed group practices for both FC Prostata and BIAB. During the first wave of the pandemic in mid-2020, there were several months when FC Prostata neither practiced nor played. The league resumed regular practices in September 2020, although league operations remain subject to regional COVID-19 restrictions and lockdown orders.

COVID-19 also suspended BIAB's paddling and indoor group fitness sessions. The group now participates bi-weekly in virtual fitness classes led by several team members with no prior experience as fitness instructors. Members also regularly socialize on group video calls after the bi-weekly PE sessions. When COVID-19 prohibited boating, outdoor fitness sessions continued during the 2020 summer and spring of 2021 , led by members of the group.

\section{Another program}

Herlev Hospital's Feel + PE program also has proved durable due to clinician recruitment and socialization linked to exercise. Like FC Prostata and BIAB, Feel + is focused on intensive exercise, not socialization; its social component evolved without supervision or guidance. The Feel + PE sessions run twice per week for three months, with participants taking part in heavy resistance exercises for 90 minutes while supervised by physiotherapists. Prior to the end of the program, the physiotherapists lead two training sessions in local fitness centers to help bridge the transition to community-based fitness. 
More than $80 \%$ of Feel + participants are on ADT because of advanced PCa, and approximately half are metastatic. Since the program's inception, participants' ages have ranged from age 50 to 90 , although the mean age is approximately 74 . Unlike FC Prostata or BIAB, recruiting for Feel + is directly from physicians who 'prescribe' the program to their PCa patients. This ensures a steady influx of new participants. However, restricting the program to patients with advanced (though not disabling) disease limits the pool from which new patients are drawn.

One group of twenty new men starts the program each month and at the end of the program, they are encouraged to continue exercising in community fitness centers. The physiotherapists do not facilitate outside social activities. Anecdotal information reported by a Feel + physiotherapist suggests that the men become closer toward the end of the training and self-organize to continue exercising together independently of the PE program.

Feel + underlines how exercise-linked socialization can lead to group durability for PE programs. It also further demonstrates how clinical recruitment can effectively seed exercise groups for PCa patients with new participants.

\section{Discussion}

Although football and dragon-boating are very different sports, BIAB and the FC Prostata appear to succeed for similar reasons. Both center on intensive $P E$, rather than just discussion about cancers or socializing. Both groups welcome PCa patients of all disease statuses and focus on group exercise, facilitated by coaches, who are patients themselves with some familiarity with the sports. Both groups are egalitarian and minimize competition to allow men of all skill and fitness levels to train together in a welcoming environment.

Both groups rely on word-of-mouth recruitment, although medical referral was important for initially seeding both BIAB and the FC Prostata teams. Spouses do not regularly attend training for either group, although they do attend some PE-linked and non-PE-linked social activities. Both groups feature regular socialization linked to $P E$, which is organized by the patients themselves. Socialization not linked to PE independently emerged as a feature of both groups.

The PE in both programs is set up to be inclusive of participants of all fitness levels. In FC Prostata, differences in skill and fitness are equalized by the coaching (following the instructional manual and the practice structure), which focuses primarily on training, not competition. For BIAB, paddlers must synchronize their strokes which forces men of different levels of fitness to work together as one [12]. This need for synchronization in the sport enforces equality and reduces competition among members of the same team. However, teams compete irregularly against other teams in tournaments and regattas, respectively. These seasonal competitions inspire participation and drive training.

Post-exercise socialization in both groups is organized by the participants and has led to additional socialization not linked to PE. These social programs have no structure nor boundaries for discussion 
topics. Men in FC Prostata and BIAB may individually elect to discuss their health, but there is no obligation or expectation that they do. As such, neither program is a formal PCa support group, yet both (as well as Feel+) have subsequently evolved into cohesive social networks, providing informal emotional and social support.

These two case studies independently suggest that the social ties that PE participants build strengthen their commitment to regular training sessions, improve their $\mathrm{QoL}[3,19]$, and ensure that they receive the physiological and psychological benefits of PE. FC Prostata and BIAB both report that PE-linked socialization is critical to their cohesion and commitment to remain physically active for the wellbeing of the team overall.

FC Prostata had to pause league activities for several months during the first wave of COVID-19 but resumed its regular schedule in late 2020. When COVID-19 controls forced social distancing in Vancouver, $B I A B$ pivoted to socially distanced outdoor $P E$. BIAB subgroups emerged for BIAB members interested in socially distanced golf and bicycling. When it became too cold to continue exercising outside, the BIAB team started bi-weekly video PE. Video socializing after PE maintained and extended the existing social support among team members.

The two groups differ in their scale. FC Prostata maintains twenty teams across Denmark, while BIAB is a single club based in a single Canadian city. Both groups use word-of-mouth recruitment, but FC Prostata has active recruitment support from local hospitals that has enabled it to scale up quickly. FC Prostata is partnered with several oncology departments who refer their patients to the league. In contrast, BIAB has a much smaller catchment area and does not have comparable ongoing recruitment via medical referrals.

The main ongoing challenge that both programs face is recruitment. As participants undergo treatment, acquire injuries and age-related physical limitations, or pass away, teams need to recruit new men to replace them. FC Prostata's success in partnering with Danish hospitals suggests that for country-wide league programs, medical professionals may be the key to leagues' expansion. Once established, though, the most significant factor in recruitment for both FC Prostata and BIAB has been word-of-mouth. The selling point for both is the combination of exercise and socialization.

\section{Limitations}

There are several limitations to our study. We present just two case studies. A randomized control trial would be needed to confirm the effectiveness of the BIAB and FC Prostata model for producing sustainable exercise programs for PCa patients. Data collection for both programs was informal, and obtained through stakeholder interviews, rather than more formal methodologies used in clinical trials. In terms of growth potential, the BIAB dragon-boating team is unique, and it is not clear whether other PCa teams will proliferate the way that breast cancer dragon-boating teams have worldwide. We did not have detailed information on the demographics of the FC Prostata players. The members of both FC Prostata and $B I A B$ were predominantly white, well-educated and of higher socioeconomic status, which may limit the generalizability of our observations. 


\section{Conclusion}

A major problem with structured research PE programs for PCa patients has been 'reversibility' when the patients drop out of their programs, either during or after the end of research trials [28]. Our case studies on FC Prostata and BIAB highlight key features of team sports that may help make them sustainable for PCa patients outside of clinical trials. Most notably, they combine PE and social activity where the socialization evolved spontaneously from the exercise activities. PE sustainability appears to be driven by the link between socializing and exercise. Socialization linked to exercise appears to help both programs remain durable, while medical recruitment appears to have helped scale up of FC Prostata to a national program.

FC Prostata, BIAB and Herlev Hospital's Feel + program all started specifically as PE programs, but naturally evolved social programming then linked to the exercise. The subsequent social activities help to sustain the PE regimes. The initial socialization involved social drinking or eating organized by the patients themselves directly following practices. Our case studies suggest that socialization organized by patients right after exercising is important for building fellowship and strengthening patients' commitment to both PE for themselves and social support for others.

These case studies point to a role for cancer centers and oncologists in promoting sports teams for PCa patients. PE programs, we suggest, may have a good chance of being self-sustaining if they are: 1) centered around intense PE, 2) of a team nature, 3) structured to promote egalitarianism and avoid oneon-one competition within teams, but 4) have some competitions between teams. Given the massive benefits of PE for PCa patients, we look forward to seeing more research on factors that make exercise programs sustainable.

\section{Declarations}

Funding: Not applicable.

Conflicts of interest/Competing interests: Not applicable.

Availability of data and material: Data available on request from the authors.

Code availability: Not applicable.

Authors' contributions: Richard J. Wassersug and Isaac Nikolai Fox both conceptualized and executed the research. Isaac Nikolai Fox wrote the article; both authors edited it prior to submission.

Ethics approval: Not applicable.

Consent to participate: Not applicable.

Consent for publication: Not applicable. 


\section{Acknowledgments}

We have received support from a number of researchers, patients, and exercise facilitators. Drs. Brigitta Rassmussen Villumsen, Jacob Uth, and Eik Bjerre all corresponded with us and provided data on PCa PE programs. Anders Ostergaard, a project manager for FC Prostata and Jeppe Højberg, a FC Prostata coach, shared their knowledge about FB Prostata. Anne-Mette Ragle, a physiotherapist who helps coordinate Herlev Hospital's exercise programs, shared her observations about the Feel+ program. Gervais Fox and Vince Schiralli shared with us their knowledge as founding and long-term members of the BIAB team. We thank them all for their help.

\section{References}

1. Baguley BJ, Bolam KA, Wright ORL, Skinner TL (2017) The effect of nutrition therapy and exercise on cancer-related fatigue and quality of life in men with prostate cancer: a systematic review. Nutrients 9:. https://doi.org/10.3390/nu9091003

2. Benedict C, Dahn JR, Antoni MH et al (2015) Positive and negative mood in men with advanced prostate cancer undergoing androgen deprivation therapy: considering the role of social support and stress. Psychooncology 24:932-939. https://doi.org/10.1002/pon.3681

3. Bergengren O, Enblad AP, Garmo $\mathrm{H}$ et al (2020) Changes in lifestyle among prostate cancer survivors: A nationwide population-based study. Psychooncology 29:1713-1719. https://doi.org/10.1002/pon.5513

4. Bjerre ED, Brasso K, Jørgensen AB et al (2019) Football compared with usual care in men with prostate cancer (FC Prostate community trial): a pragmatic multicenter randomized controlled trial. Sports Med 49:145-158. https://doi.org/10.1007/s40279-018-1031-0

5. Bjerre ED, Petersen TH, Jørgensen AB et al (2019) Community-based football in men with prostate cancer: 1-year follow-up on a pragmatic, multicenter randomized controlled trial. PLoS Med 16:. https://doi.org/10.1371/journal.pmed.1002936

6. Bourke L, Homer KE, Thaha MA et al (2013) Interventions for promoting habitual exercise in people living with and beyond cancer. Cochrane Database of Systematic Reviews. https://doi.org/10.1002/14651858.CD010192.pub2

7. Bourke L, Smith D, Steed L et al (2016) Exercise for men with prostate cancer: a systematic review and meta-analysis. Eur Urol 69:693-703. https://doi.org/10.1016/j.eururo.2015.10.047

8. Bruun DM, Bjerre E, Krustrup P et al (2014) Community-based recreational football: a novel approach to promote physical activity and quality of life in prostate cancer survivors. Int J Environ Res Public Health 11:5567-5585. https://doi.org/10.3390/ijerph110605567

9. Campos C, Sotomayor P, Jerez D et al (2018) Exercise and prostate cancer: From basic science to clinical applications. Prostate 78:639-645. https://doi.org/10.1002/pros.23502

10. Capistrant BD, Lesher L, Kohli $\mathrm{N}$ et al (2018) Social support and health-related quality of life among gay and bisexual men with prostate cancer. Oncol Nurs Forum 45:439-455. 
https://doi.org/10.1188/18.0NF.439-455

11. Chan $P$ (2019) Breast cancer survivors find strength, healing in dragon boat racing. In: CTV News. https://toronto.ctvnews.ca/breast-cancer-survivors-find-strength-healing-in-dragon-boat-racing1.4522541. Accessed 12 Jan 2021

12. Cinà IV, Sebastiano KMD, Faulkner GE (2020) "One stroke, with twenty-two people": exploring prostate cancer survivors' participation in dragon boating. J Psychosoc Oncol 38:375-388. https://doi.org/10.1080/07347332.2020.1725215

13. Colloca G, Colloca P (2016) The effects of social support on health-related quality of life of patients with metastatic prostate cancer. J Cancer Educ 31:244-252. https://doi.org/10.1007/s13187-0150884-2

14. Cormie P, Galvão DA, Spry N et al (2015) Can supervised exercise prevent treatment toxicity in patients with prostate cancer initiating androgen-deprivation therapy: a randomized controlled trial. BJU Int 115:256-266. https://doi.org/10.1111/bju.12646

15. Cormie P, Zopf EM (2020) Exercise medicine for the management of androgen deprivation therapyrelated side effects in prostate cancer. Urologic Oncology: Seminars Original Investigations 38:6270. https://doi.org/10.1016/j.urolonc.2018.10.008

16. Culos-Reed S, Dew M, Shank J et al (2019) Qualitative evaluation of a community-based physical activity and yoga program for men living with prostate cancer: survivor perspectives. Glob Adv Health Med 8:216495611983748. https://doi.org/10.1177/2164956119837487

17. Dawson JK, Dorff TB, Todd Schroeder E et al (2018) Impact of resistance training on body composition and metabolic syndrome variables during androgen deprivation therapy for prostate cancer: a pilot randomized controlled trial. BMC Cancer 18:368. https://doi.org/10.1186/s12885-0184306-9

18. DBU Medlemstal. In: DBU. https://www.dbu.dk/om-dbu/medlemstal/. Accessed 31 Jan 2021

19. Eom C-S, Shin DW, Kim SY et al (2013) Impact of perceived social support on the mental health and health-related quality of life in cancer patients: results from a nationwide, multicenter survey in South Korea. Psychooncology 22:1283-1290. https://doi.org/10.1002/pon.3133

20. Galvão DA, Taaffe DR, Spry N et al (2009) Reduced muscle strength and functional performance in men with prostate cancer undergoing androgen suppression: a comprehensive cross-sectional investigation. Prostate Cancer Prostatic Dis 12:198-203. https://doi.org/10.1038/pcan.2008.51

21. Galvão DA, Taaffe DR, Spry N et al (2010) Combined resistance and aerobic exercise program reverses muscle loss in men undergoing androgen suppression therapy for prostate cancer without bone metastases: a randomized controlled trial. J Clin Oncol 28:340-347. https://doi.org/10.1200/JC0.2009.23.2488

22. Galvão DA, Taaffe DR, Spry N et al (2018) Exercise preserves physical function in prostate cancer patients with bone metastases. Med Sci Sports Exerc 50:393-399. https://doi.org/10.1249/MSS.0000000000001454 
23. Harris SR (2012) "We're all in the same boat": a review of the benefits of dragon boat racing for women living with breast cancer. Evid Based Complement Alternat Med 2012:167651. https://doi.org/10.1155/2012/167651

24. Hart NH, Galvão DA, Newton RU (2017) Exercise medicine for advanced prostate cancer. Curr Opin Support Palliat Care 11:247-257. https://doi.org/10.1097/SPC.0000000000000276

25. Kadambi S, Soto-Perez-de-Celis E, Garg T et al (2020) Social support for older adults with cancer: Young International Society of Geriatric Oncology review paper. J Geriatr Oncol 11:217-224. https://doi.org/10.1016/j.jgo.2019.09.005

26. Keilani M, Hasenoehrl T, Baumann L et al (2017) Effects of resistance exercise in prostate cancer patients: a meta-analysis. Support Care Cancer 25:2953-2968. https://doi.org/10.1007/s00520-017$3771-z$

27. Kenfield SA, Stampfer MJ, Giovannucci E, Chan JM (2011) Physical activity and survival after prostate cancer diagnosis in the health professionals follow-up study. J Clin Oncol 29:726-732. https://doi.org/10.1200/JCO.2010.31.5226

28. Neil-Sztramko SE, Medysky ME, Campbell KL et al (2019) Attention to the principles of exercise training in exercise studies on prostate cancer survivors: a systematic review. BMC Cancer 19:321. https://doi.org/10.1186/s12885-019-5520-9

29. Newton RU, Kenfield SA, Hart NH et al (2018) Intense exercise for survival among men with metastatic castrate-resistant prostate cancer (Interval-GAP4): a multicenter, randomized, controlled phase III study protocol. BMJ Open 8. https://doi.org/10.1136/bmjopen-2018-022899

30. Schmidt MLK, Østergren P, Cormie P et al (2019) "Kicked out into the real world": prostate cancer patients' experiences with transitioning from hospital-based supervised exercise to unsupervised exercise in the community. Support Care Cancer 27:199-208. https://doi.org/10.1007/s00520-0184306-y

31. Segal RJ, Reid RD, Courneya KS et al (2009) Randomized controlled trial of resistance or aerobic exercise in men receiving radiation therapy for prostate cancer. J Clin Oncol 27:344-351. https://doi.org/10.1200/JC0.2007.15.4963

32. Smith MR, Saad F, Egerdie B et al (2012) Sarcopenia During Androgen-Deprivation Therapy for Prostate Cancer. J Clin Oncol 30:3271-3276. https://doi.org/10.1200/JC0.2011.38.8850

33. Uth J, Fristrup B, Haahr RD et al (2018) Football training over 5 years is associated with preserved femoral bone mineral density in men with prostate cancer. Scand J Med Sci Sports 28(Suppl 1):6173. https://doi.org/10.1111/sms.13242

34. Uth J, Hornstrup T, Christensen JF et al (2016) Football training in men with prostate cancer undergoing androgen deprivation therapy: activity profile and short-term skeletal and postural balance adaptations. Eur J Appl Physiol 116:471-480. https://doi.org/10.1007/s00421-015-3301-y

35. Uth J, Schmidt JF, Christensen JF et al (2013) Effects of recreational soccer in men with prostate cancer undergoing androgen deprivation therapy: study protocol for the "FC Prostate" randomized controlled trial. BMC Cancer 13:595. https://doi.org/10.1186/1471-2407-13-595 
36. Windsor PM, Nicol KF, Potter J (2014) A randomized, controlled trial of aerobic exercise for treatmentrelated fatigue in men receiving radical external beam radiotherapy for localized prostate carcinoma. Cancer 101:550-557. https://doi.org/10.1002/cncr.20378

37. Yang B, Wang J (2017) Effects of exercise on cancer-related fatigue and quality of life in prostate cancer patients undergoing androgen deprivation therapy: a meta-analysis of randomized clinical trials. Chin Med Sci J 32:13-21. https://doi.org/10.24920/j1001-9242.2007.002

38. Yunfeng $G$, Weiyang $H$, Xueyang $H$ et al (2017) Exercise overcome adverse effects among prostate cancer patients receiving androgen deprivation therapy: An update meta-analysis. Medicine 96:. https://doi.org/10.1097/MD.0000000000007368 